\title{
PERANCANGAN SISTEM PENGAJUAN KEGIATAN PENGABDIAN MASYARAKAT MAHASISWA BERSAMA DOSEN STIKOM BALI
}

\author{
NYOMAN AYU NILA DEWI ${ }^{1}$, PUTU DESIANA WULANING AYU ${ }^{2}$ \\ Jl.Raya Puputan Renon No.86 Denpasar ${ }^{1,2}$ \\ Sistem Informasi ${ }^{1}$, Sistem Komputer ${ }^{2}$, STIKOM Bali , Denpasar \\ e-mail: ayu.nila8@yahoo.co.id ${ }^{1}$
}

\begin{abstract}
Abstrak
Pengabdian merupakan salah satu bagian dari tri darma perguruan tinggi yang wajib dilaksanakan oleh dosen di suatu perguruan tinggi. Tidak hanya dosen saja mahasiswa juga diwajibkan untuk melakuka kegiatan pengabdian masyarakat. Seperti halnya mahasiswa STMIK STIKOM Bali yang bergabung dalam berbagai unit kegiatan mahasiswa dengan mengagendakan kegiatan pengabdian mayarakat bersama dosen. Namun untuk kegiatan pengabdian masyarakat bersama mahasiswa saat ini masih secara manual proses pengajuan nya. Dilihat dari proses pengajuan surat ke unit P2M yang harus diteruskan ke bagian PK1 dan menunggu konfirmasi kesediaan dosen untuk mengikuti kegiatan tersebut. Melihat prosedur yang maual tersebut dengan membutuhkan waktu yang panjang maka dalam penelitian ini aka dibuat suatu perancangan sistem yang dapat membentuk awal dari implementasi sistem yang akan di bangun. Hasil dari penelitian ini yang telah dikerjakan adalah dalam penelitian ini telah menciptakan perancangan suatu sistem untuk perancangan sistem pengajuan kegiatan pengabdian mahasiswa. Hasil penelitian ini telah mebahas diagram konteks, data flow diagram level 0, ERD, konseptual database, struktur tabel dan interface sistem untuk pengembangan sistem tahap berikutnya
\end{abstract}

Kata kunci-Pengabdian Masyarakat, Sistem, Mahasiswa

\begin{abstract}
Devotion is one part of the tri dharma college that must be implemented by the lecturer in a college. Not only lecturers course students are also required to melakuka community service activities. As any student of STMIK STIKOM Bali are joining in the various units of student activities with scheduled service activities together lecturers society. But for the community service activities with students today still manually filing process it. Judging from the process of applying for a unit to P2M to be forwarded to the PKI and wait for confirmation of the willingness of professors to the event. Viewed maual procedures with taking a long time in this study aka created a system design that can form the beginning of the implementation of the system will be built. The results of this research has been done is in this research has created the design of a system for filing system design student service activities. The results of this study have been mebahas context diagram, data flow diagram level 0, ERD, conceptual database, table structure and interface system for the next phase of system development
\end{abstract}

Keywords - System Information, Learning, Design

\section{PENDAHULUAN}

Pengabdian masyarakat merupkan salah satu tri dharma perguruan tinggi yang wajib dilaksanakan oleh para dosen setiap semesternya. Pengabdian masyarakat merupakan suatu bentuk kegiatan sosial kita sebagai tenaga pendidik ke masyarakat. Hal ini menjadi salah satu kegiatan yang penting dan wajib untuk dapat membantu serta menyebarkan pengetahuan ke masyarakat. Pengabdian masyarakat yang dilakukan itu dikelompokan berdasarkan berbagai kegiatan seperti kelompok pelatihan, bakti sosial, penyuluhan, serta pemberian materi dalam seminar atau pembicara dalam seminar. 
Kegiatan pengabdian masyrakat sering dijumpai pada institusi pendidikan, banyak kegiatan yang ada dan telah dilakukan oleh para dosen untuk dapat menyebarluaskan berbagai informasi tentang pendidikan, teknologi, keterampilan, sosial dan lain sebagainya. Di STMIK STIKOM Bali sendiri kegiatan pengabdian wajib dilakukan oleh dosen untuk setiap semesternya.Kegiatan pengabdian masyarakat juga wajib dilakukan oleh mahasiswa dan UKM yang ada di lingkungan kampus. Kegiatan ini diwajibkan oleh perguruan tinggi agar mahasiswa dapat bersosialisasi dengan masyarakat dan belajar untuk membantu serta berkontribusi dalam misi menyebarkan ilmu pengetahuan.

Di STMIK STIKOM Bali sendiri mahasiswa yang tergabung dalam UKM yaitu Unit Kegiatan Mahasiswa diwajibkan untuk membuat agenda kegiatan pengabdian masyarakat untuk 1 periode kepengurusan. Alur dari kegiatan pengabdian mereka dimana setiap pengurus menentukan kegiatan pengabdian yang akan dilakukan dan lokasi serta jenis pengabdian yang akan diberikan ke masyarakat. Setelah penentuan jenis kegiatan pengabdian dan waktu pengabdian maka mahasiswa diminta untuk membuat proposal pengajuan dana dan proposal kegiatan ke bagian PK3, unit ini merupakan bagian yang mengatur dan mengelola kegiatan mahasiswa.

Setelah proposal diajukan ke bagian PK3 dan di setujui untuk diadakan kegiatan maka mahasiswa tersebut harus mengajukan permintaan dosen yang mendampingi dan keikutsertaan dosen dalam kegiatan terus. Proses tersebut dilakukan oleh mahasiswa secara manual dengan membawa surat pengajuan dan proposal kegiatan ke unit P2M yang sebagai unit dalam pengelola kegiatan pengabdian dan penelitian dosen. Setelah pengajuan surat tersebut maka mahasiswa harus menunggu konfirmasi dari pihak pengelola kegiatan pengabdian, dimana prosedur dari surat yang diajukan mahasiswa tersebut akan di teruskan kembali ke bagian PK1 untuk diminta data list dosen yang akan mengikuti kegiatan pengabdian.

Setelah surat tersebut diteruskan maka akan menunggu konfirmasi dari pihak pengelola dosen yang akan di sampaikan ke bagian P3M yang selanjutnya akan diinformasikan ke mahasiswa. Alur yang manual tersebut menyebabkan banyak sekali proses yang harus di lalui dan membutuhkan waktu yang cukup panjang karena menyeseuaikan dengan kegiatan yang ada di setiap unit. Melihat dari permasalahan tersebut maka dalam penelitian ini akan dirancang suatu sistem dimana mahasiswa dapat mengajukan kegiatan oengabdian masyarakat bersama dosen langsung melalui sistem.

Dimana alur dalam sistem nanti mahasiswa akan mengajukan surat kegiatan pengabdian bersama mahasiswa melalui sistem dan di tembuskan ke bagian PK1 selaku pengelola dosen. Sehingga surat dan informasi tersebut lebih cepat sampai ke bagian PK1 dan informasi dosen yang ikut serta dalam kegiatan jadi lebih cepat informasinya. Dimana hasil dari penelitian ini nantinya berupa suatu perancangan sistem dengan pengujian perancangan dari sistem tanpa membangun sistem yang akan diusulkan, dari perancangan sistem ini diharapkan nantinya dapat dibangun sistem untuk mempermudah implementasi sistem. Dari latar belakang yang telah diuraikan sebelumnya maka rumusan masalah yang akan di bangun dalam penelitian ini adalah bagaimana Sistem Pengajuan Kegiatan Pengabdian Masyarakat Mahasiswa Bersama Dosen STIKOM Bali?

Batasan masalah dalam penelitian ini adalah penelitian ini dibatasi adalah untuk perancangan sistem pengajuan kegiatan pengabdian masyarakat ini dikhususkan untuk pengabdian masyarakat yang dilakukan mahasiswa bersama dosen dan pengelolaaanya berada pada unit P2M STIKOM Bali

\section{METODE PENELITIAN}

Pada bab ini akan menjelaskan alur dari penelitian yang akan dilaksanakan. Alur penelitian yang dilakukan seperti pada gambar di bawah ini: 


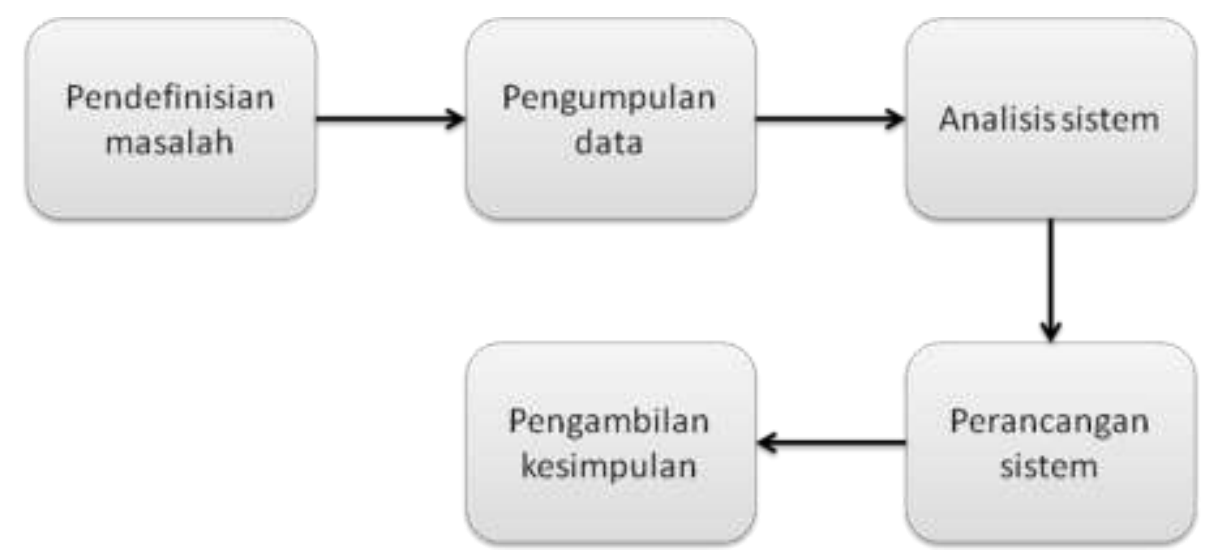

\section{Gambar 1 Alur Penelitian}

Bagian ini akan menjelaskan mengenai tahapan dalam penelitian. Alur penelitian yang dilakukan adalah sebagai berikut :

1. Pendefinisian masalah

Pendefinisian permasalahan dari sistem yang ingin dirancang untuk menambah pemahaman mengenai hal tersebut.

\section{Pengumpulan data}

Pengumpulan data dilakukan dengan mengumpulkan data yang berhubungan dengan perancangan sistem informasi administrasi penelitian. Metode pengumpulan data terdiri dari beberapa tahap yaitu :

a) Metode Observasi

Merupakan metode pengumpulan data dengan cara melakukan pengamatan terhadap objek penelitian secara langsung dan kemudian menarik kesimpulan dari seluruh kegiatan pada objek tersebut. Observasi dilakukan pada P2M STIKOM Bali.

b) Metode Wawancara

Merupakan metode pengumpulan data melalui tatap muka secara langsung dengan pihakpihak tertentu, dalam hal ini adalah staf yang menangani sub bagian pengabdian masyarakat STIKOM Bali dan mahasiswa yang melakukan kegiatan pengabdian.

c) Metode Studi Pustaka

Pengumpulan data dengan cara membaca dan mamahami terhadap literatur, buku, artikel maupun bahan kepustakaan yang berhubungan dengan masalah yang sedang diteliti.

3. Analisis Sistem

Analisis sistem merupakan pemahaman akan proses-proses yang terjadi sehingga dapat dilakukan suatu pemodelan sistem. Analisis sistem dilakukan dengan mengidentifikasi permasalahan yang terjadi dalam proses administrasi penelitian. Hasil dari analisis permasalahan akan digunakan dalam perancangan sistem yang diperlukan.

4. Perancangan Sistem

Perancangan sistem dalam penelitian ini berdasarkan hasil analisis. Perancangan sistem merupakan perancangan sistem menggunakan Data Flow Diagram (DFD) dan Entity Relationship Diagram (ERD). Pada tahap ini juga dilakukan perancangan basis data sistem serta perancangan user interface. 
5. Pengambilan kesimpulan

Tahap ini menyimpulkan hasil penelitian yang dilakukan

6. Teknik Pengumpulan Data

Teknik pengumpulan data dalam penelitian ini data yang

\section{HASIL DAN PEMBAHASAN}

\section{Prosedur yang sedang berjalan}

Penelitian ini membahas tentang proses pengajuan proposal kegiatan mahasiswa yang ada di STIKOM Bali yang bekerjasama dengan dosen. Dimana alur dari pengajuan tersebut mahasiswa dari UKM harus mengirimkan proposal ke bagian kemahasiswaan dan diserahkan langsung ke bagian P2M yang selanjutnya akan dilakukan suatu proses verifikasi proposal apakah proposal merupakan kegiatan PM atau tidak. Jika kegiatan tersebut PM maka akan di data oleh pihak P2M dan selanjutnya mahasiswa mengirimkan surat pengajuan untuk mengundang beberapa dosen yang akan menjadi pendamping dalam kegiatan tersebut.

Surat pengajuan dosen terbagi menjadi dua dimana pengajuan untuk pendamping dosen prodi atau pendamping dosen dari P2M unit yang menangani kegiatan mahasiswa. Adapun alur proses pengajuan proposal dapat dilihat pada gambar 1 flowchart alur sistem.

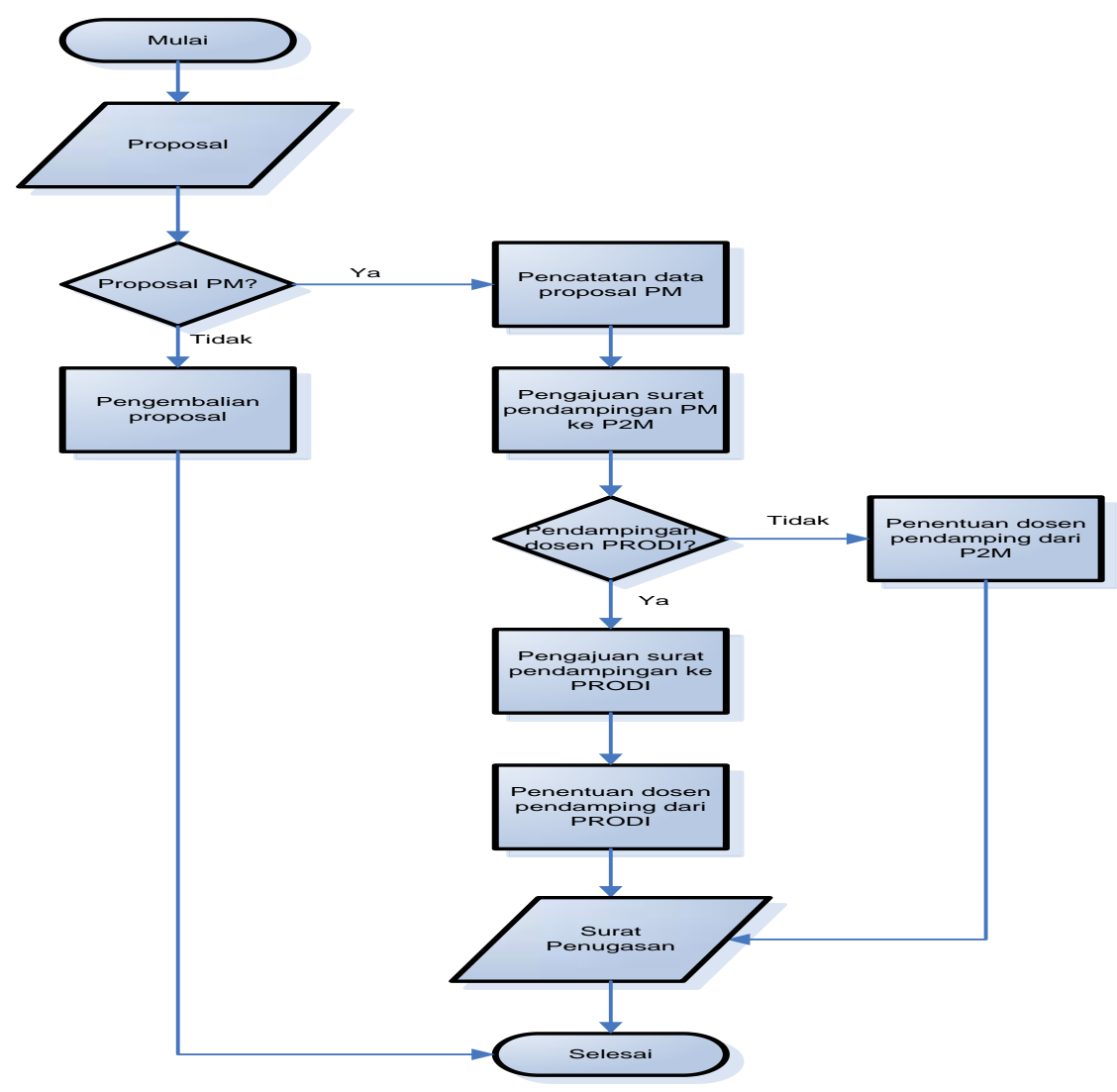

Gambar 2. Alur sistem

\section{Kebutuhan}

Kebutuhan fungsional dari sistem adalah sebagai berikut :

1. Sistem mampu melakukan penginputan data pengajuan proposal kegiatan 
a. Pengguna dapat memasukkan data terkait proposal kegiatan yang dilakukan meliputi : judul kegiatan, tanggal pelaksanaan kegiatan, lokasi kegiatan, penyelenggara kegiatan dan lainnya

b. Pengguna dapat menampilkan seluruh data proposal kegiatan yang diajukan.

c. Pengguna dapat melakukan perubahan terhadap data pengajuan proposal kegiatan

2. Verifikasi Kegiatan

Pengguna dapat melakukan verifikasi terhadap proposal kegiatan yang diajukan

3. Pengajuan surat pendampingan kegiatan

a. Pengguna dapat menginputkan data surat pendampingan kegiatan

b. Pengguna dapat melihat seluruh data surat pendampingan kegiatan

c. Pengguna dapat melakukan perubahan terhadap data surat pendampingan kegiatan

\section{Kebutuhan Non Fungsional}

Analisis kebutuhan non fungsional dilakukan untuk mengetahui spesifikasi kebutuhan untuk sistem. Spesifikasi kebutuhan melibatkan analisis perangkat keras/hardware,analisis perangkat lunak/software, analisis pengguna/user.

\section{Analisis Perangkat keras/Hardware}

Komputer dengan spesifikasi sebagai berikut:

a) Processor : Intel Pentium Dual Core@ $2.0 \mathrm{Ghz}$

b) Harddisk : $80 \mathrm{~Gb}$

c) Memory : $1024 \mathrm{Mb}$

d) VGA : $128 \mathrm{Mb}$

e) Monitor : LCD 15",

f) Mouse dan Keyboard

\section{Analisis Perangkat Lunak/Software}

Perangkat lunak (software) yang digunakan adalah sebagai berikut:

a. Sistem Operasi : Microsofot Windows

b. Software lainnya : Microsoft Office 2007

Spesifikasi perangkat lunak yang dibutuhkan untuk mendukung aplikasi yang akan dibangun adalah sebagai berikut:

a) Sistem Operasi Windows XP Service Pack 1

b) Macromedia Dreamweaver

c) XAMPP

d) Mozilla firefox,Internet Explorer dan Opera sebagai browser

e) Microsoft Visio

\section{Analisis Pengguna/User}

Pengguna dalam aplikasi ini dibedakan menjadi tiga user yaitu :

1. Mahasiswa

Mahasiswa adalah user yang hanya dapat melakukan penginputan data pengajuan proposal

PM dan melihat data yang telah dinputkan.

2. $\mathrm{P} 2 \mathrm{M}$ 
P2M adalah staf bagian penelitian dan pengabdian masyarakat yang terdapat dalam STIKOM Bali. P2M mempunyai akses untuk melihat seluruh list pengajuan proposal yang dilakukan oleh user mahasiswa. P2M juga mempunyai hak akses untuk menginputkan pengajuan surat pendampingan ke Prodi dan informasi balasan dari prodi

3. Prodi

Prodi adalah bagian program studi yang mempunyai hak askses untuk melihat data pengajuan pendampingan oleh $\mathrm{P} 2 \mathrm{M}$ dan memberikan feedback berupa menginputkan data dosen yang diberikan tugas untuk mendampingi kegiatan pengabdian mahasiswa.

\section{Perancangan Sistem}

Dari gambar alur sistem tersebut maka untuk penggambaran aliran data dapat digambarkan pada gambar 2 diagram konteks

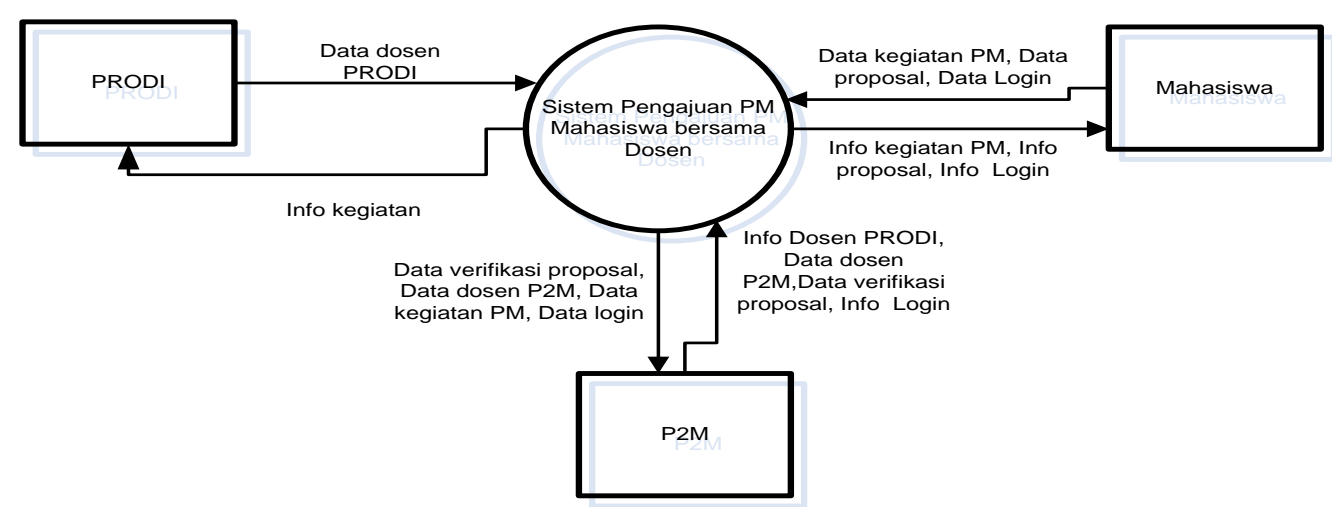

\section{Gambar 3. Digram Konteks}

Diagram konteks 2 menjelaskan bahwa sistem memiliki 3 entitas yaitu entitas P2M, mahasiswa dan Prodi dimana setiap entitas melakukan suatu proses ke dalam sistem secara bersama-sama. Dari penggambaran siagram konteks ini maka untuk selanjutnya dilakukan penggambaran data flow diagram yang menggambarkan aliran data dari suatu proses dalam sistem pengajuan proposal mahasiswa. Data flow diagram pada aliran sistem ini dapat dilihat pada gambar 3 


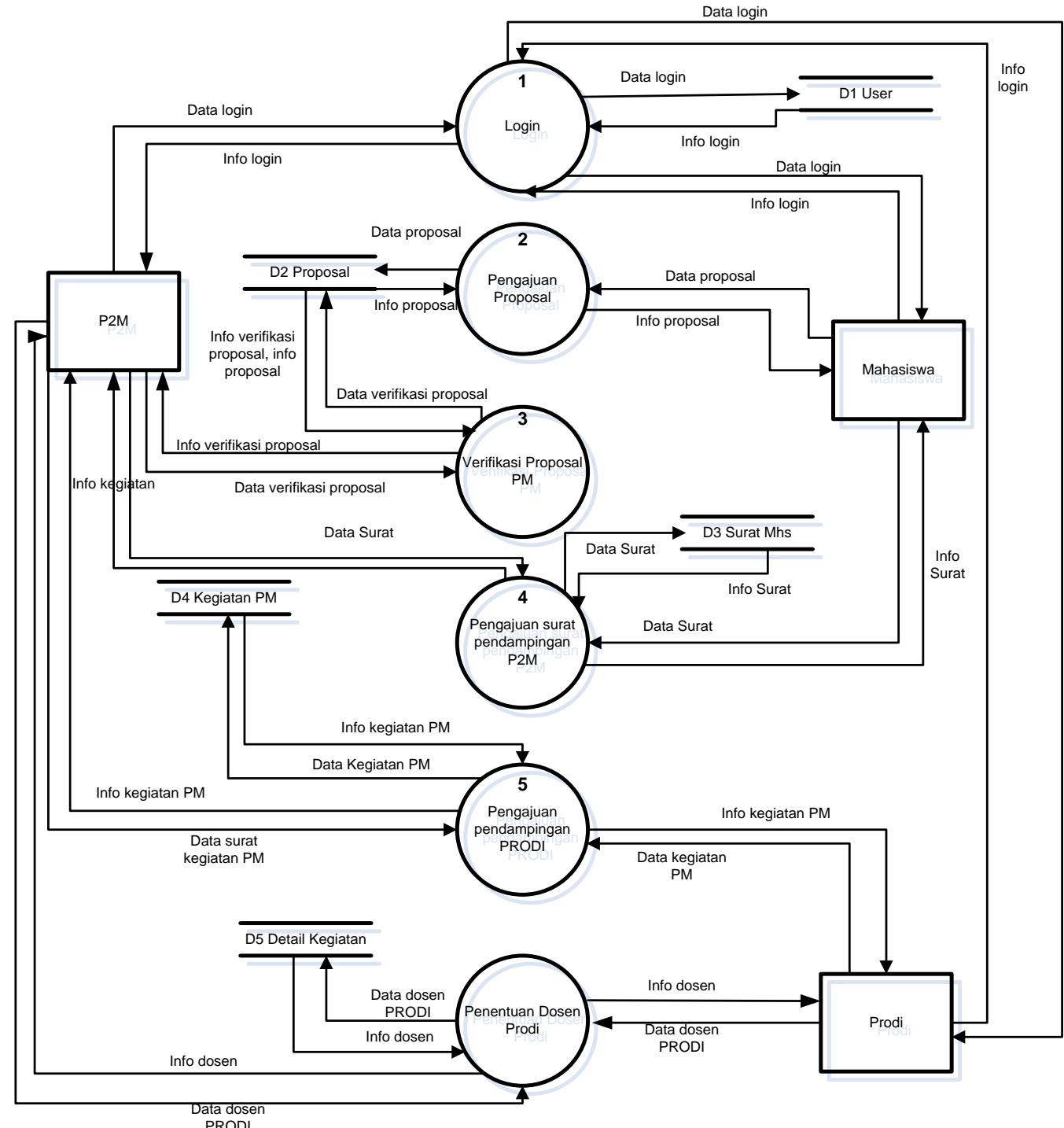

Gambar 4. Data Flow Diagram Level 1

Dari penggambaran data flow diagram diatas maka ada beberapa data yang akan digambarakan dengan perancangan entity relationship diagram. Pada permasalahan ini terdapat 4 entity yang saling berhubungan dan 1 entity yang tidak berhubungan dengan entity yang lain. Dimana dalam setiap entity digunakan untuk menyimpan data yang mengalir dalam sistem. Relasi antar entity dapat dilihat pada gambar 4. 


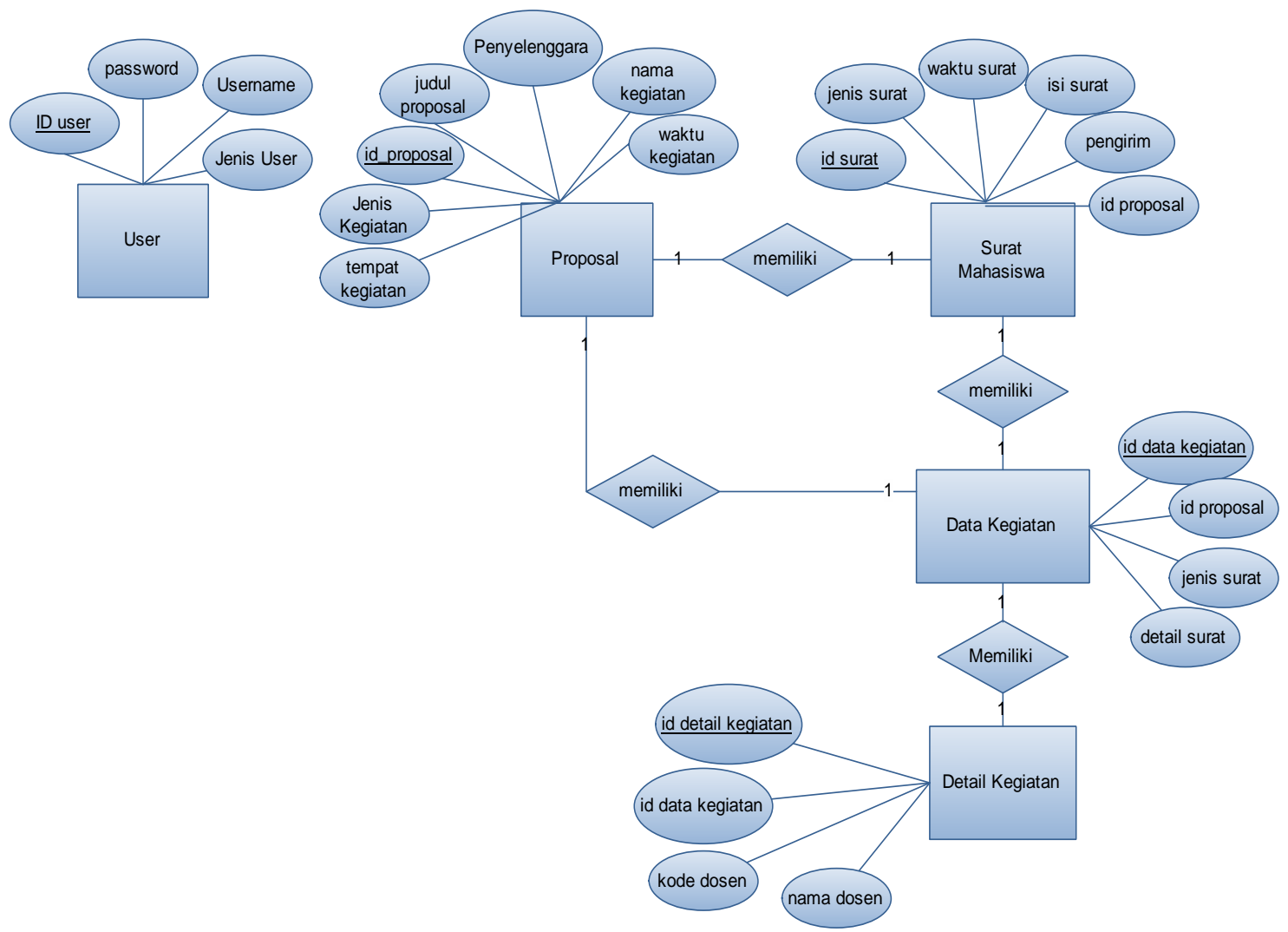

\section{Gambar 5. Entity Relasionship Diagram}

Perancangan selanjutnya menggambarkan konseptual database dari aliran data yang telah diagambarkan pada ERD. Pada konseptual database terdapat 5 tabel yang digunakan untuk menyimpan data, dimana tabel user digunakan untuk menyimpan data login user, tabel proposal digunakan untuk menyimpan data proposal yang diajukan oleh mahasiswa, tabel surat mahasiswa digunakan untuk menyimpan data surat mahasiswa yang mengajukan permohonan dosen pendamping maupun pengajar. Selanjutnya tabel data kegiata digunakan untuk menyimpan surat yang diajukan oleh $\mathrm{p} 2 \mathrm{~m}$ ke bagian PK1 yang digunakan untuk proses penentuan dosen, sedangkan tabel detail kegiatan digunakan untuk menyimpan data detail kegiatan dan dosen yang akan mengikuti kegiatan tersebut. Adapun konseptual database yang dirancang dalam penelitian ini seperti pada gambar 5 .

\begin{tabular}{|l|}
\hline \multicolumn{2}{|c|}{ User } \\
\hline Id user \\
Username \\
Password \\
Jenis User \\
\hline
\end{tabular}

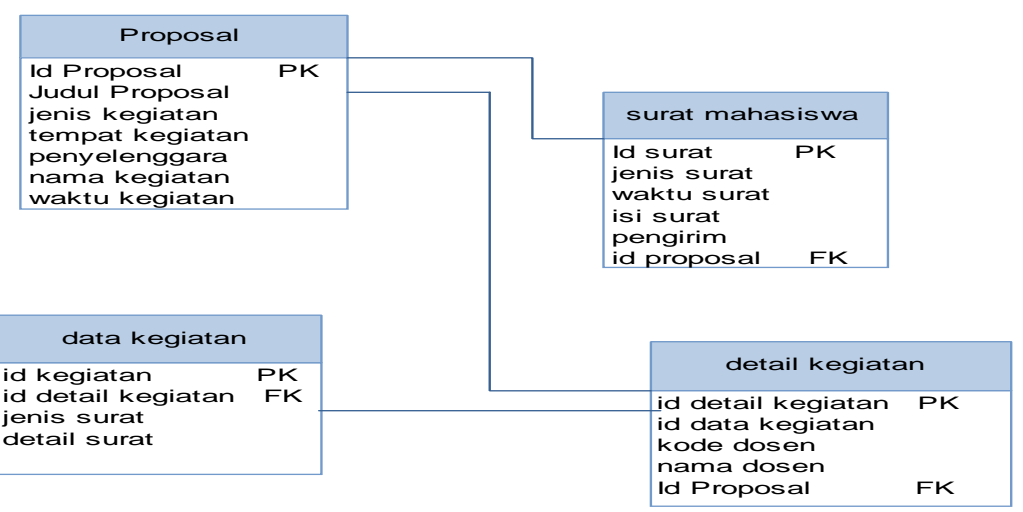

\section{Gambar 6. Konseptual database}

Perancangan sistem selanjutnya adalah perancangan tabel yang digunakan untuk menampilkan filed yang akan menjadi tempat penyimpanan data dalam sistem. Setiap tabel memiliki field yang digunakan untuk menyimpan data, dengan mengatur tipe data dan ukuran data 
yang menjadi kapasitas serta tipe karakter dalam penyimpanan. Dari perancangan sistem diatas yang telah dihasilkan dalam penelitian ini, maka untuk tampilan interface akan dirancang sesuai dengan sistem yang akan di bangun untuk tahap selanjutnya. Perancangan interface sistem yang di bangun seperti pada gambar di bawah ini.

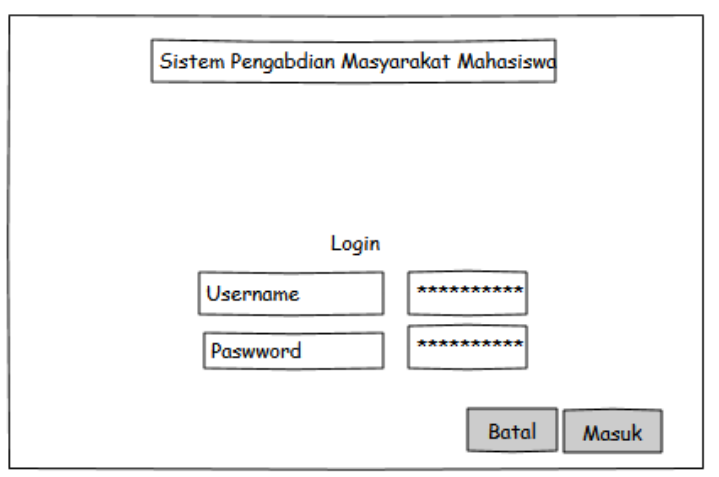

\section{Gambar 7. Form LogIn}

Form login merupakan halaman utama sebelum masuk kedalam sistem. User dapat mengimputkan user name dan pasword ke dalam halaman login.

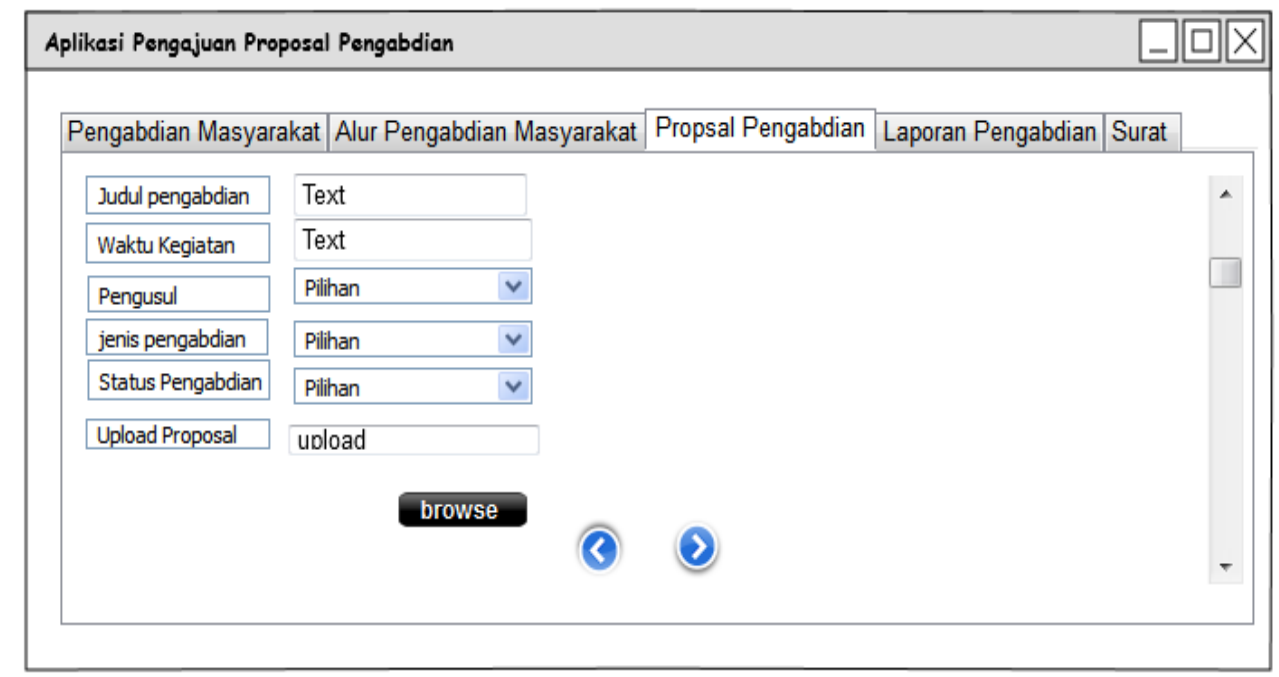

\section{Gambar 8. Form Pengajuan Proposal}

Form pengajuan proposal digunakan oleh mahasiswa untuk memasukan proposal kegiatan dengan menginputkan data sesuai dengan kolom yang harus diisi.

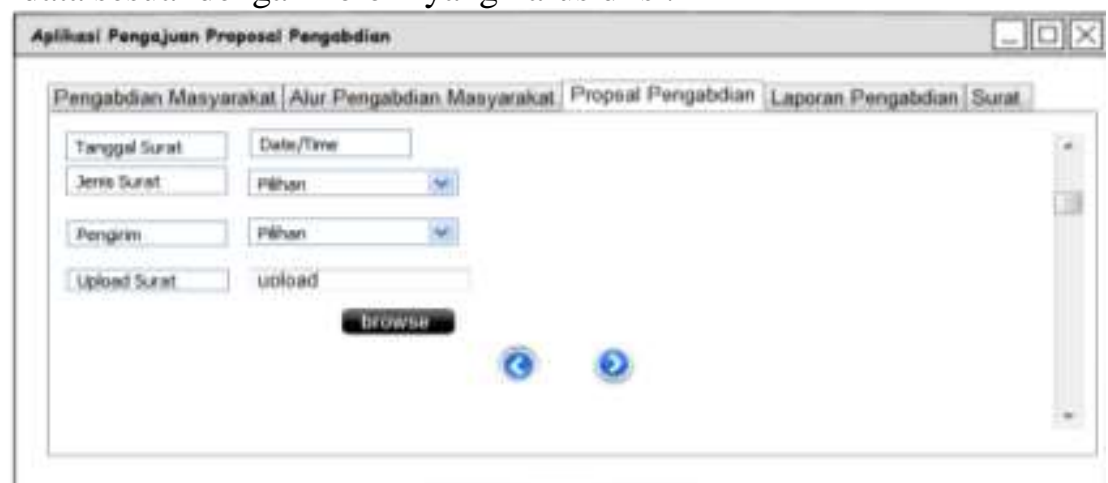

\section{Gambar 9.Form Pengajuan Surat}


Form pengajuan surat digunakan untuk menginputkan surat undangan kegiatan pengabdian masyarakat, surat yang diinputkan berupa surat kesiaan menjadi pendamping maupun surat undangan permohonan dosen yang mengikuti kegiatan,

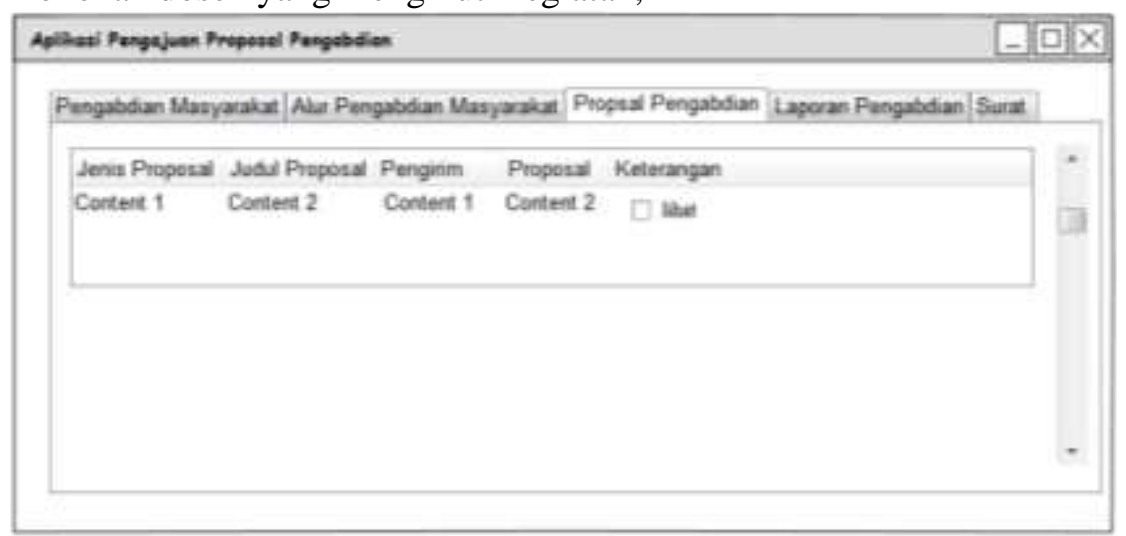

\section{Gambar 10. Form Pengecekan Proposal}

Tampilan pengecekan proposal terdapat pada halaman dosen pengelola kegiatan pengabdian, di mana dosen dapat melihat proposal yang masuk untuk kegiatan pengabdian masyarakat.

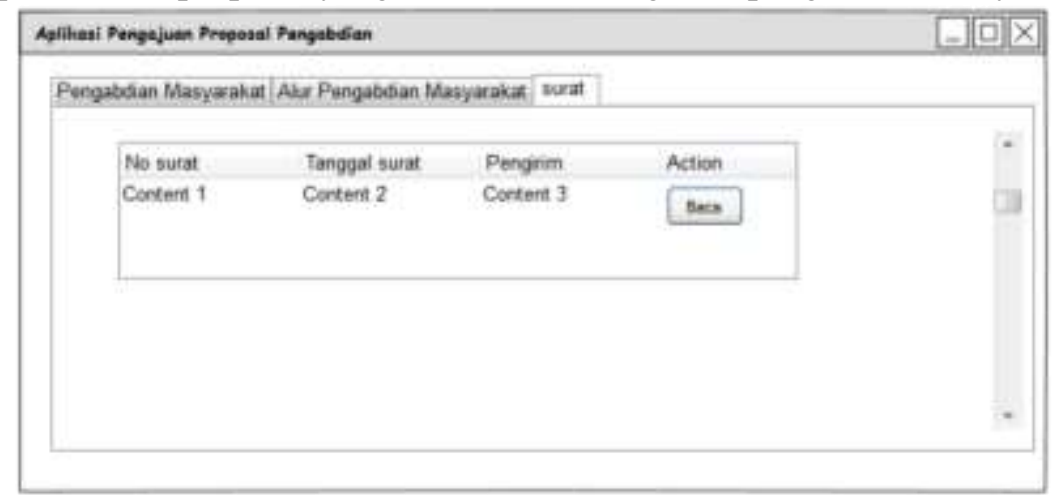

\section{Gambar11. Form Pengecekan Surat Mahasiswa}

Form 10 digunakan untuk mengecek surat masuk dari mahasiswa yang telah mengirimkan surat, tampilan ini digunakan oleh dosen pengelola pengabdian masyarakat untukmelihat data surat masuk untuk kegiatan pengabdian.

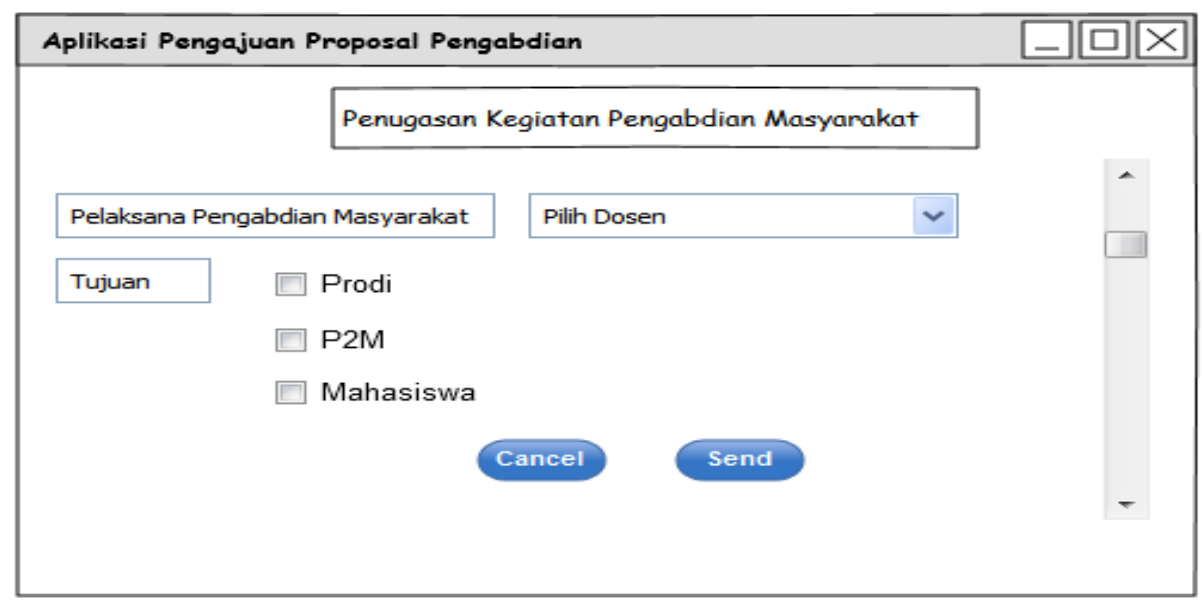

Gambar 12. Form Penentuan Tugas Pengabdian 
Form penentuan tugas merupakan tampilan dosen pengelola pengabdian masyarakat di mana setelah pengajuan surat maka seluruh data dosen yang akan dijadikan pendampingan di data melalui sistem ini serta penunjukan dilakukan melalui prodi dan pembantu ketua I.

\section{KESIMPULAN}

Kesimpulan yang dapat diambil dari penelitian ini adalah perancangan untuk sistem pengabdian masyarakat telah berhasil dirancang dengan menggambarkan perancangan diagram konteks, ERD dari data yang akan digunakan dan perancangan sistem yang akan dikembangkan.

\section{SARAN}

Dari hasil penelitian ini masih banyak memiliki kekurangan yaitu penelitian ini masih sebatas perancangan sistem untuk tahap selanjutnya diharapkan dapat mengembangkan menjadi pembangunan sistem dan pengujian dari sistem yang telah dibangun. Untuk tahap selanjutnya agar dirancang lebih mendetail untuk aliran data dari sistem dan pengujian sistem yang akan di bangun

\section{UCAPAN TERIMA KASIH}

Penyelesaian penelitian ini tidak terlepas dari peranan penting dari prodi jurusan masingmasing pengusul yang memberikan informasi dan mewadahi penelitian ini. Peneliti juga mengucapkan terimakasih kepada STIKOM Bali yang telah memberikan dana untuk terselesaikannya penelitian ini.

\section{DAFTAR PUSTAKA}

1. Jogiyanto, H.M. (2005). Analisis dan Desain. Yogyakarta: ANDI.

2. Kendall and Kendall. (2008). System Analysis and Design. Seventh ed.; New Jersey: Prentice Hall.

3. Rika, Michael Yoseph Ricky. (2010). Analisis Dan Perancangan Sistem Informasi Laboratorium Rumah Sakit Kanker Dharmais Dengan Menggunakan Total Architecture Syntesis. $\underline{\text { ComTech. Vol 1. No 2. 2010. }}$.

4. Swastikayana, I Wayan Eka. Sistem Informasi Geografis Berbasis WebUntuk Pemetaan Pariwisata Kabupaten Gianyar. Skripsi. Yogyakarta. 2011 